\title{
Trichogramma pretiosum in field release and under different temperatures in laboratory
}

\author{
Trichogramma pretiosum em liberação no campo e sob diferentes \\ temperaturas em laboratório
}

\author{
Rosana Matos de Morais 1* (1) (https://orcid.org/0000-0002-2694-4646) \\ Tamires Silveira Moro ${ }^{2}$ (1) (https://orcid.org/0000-0002-0966-7309) \\ Cleber Witt Saldanha' (1) (https://orcid.org/0000-0001-6147-6027) \\ Gerusa Pauli Kist Steffen ${ }^{1}$ (1) (https://orcid.org/0000-0002-0464-567X) \\ Evandro Luiz Missio' (1) (https://orcid.org/0000-0002-8582-0301) \\ Joseila Maldaner ${ }^{1}$ (1) (https://orcid.org/0000-0002-3008-5047) \\ Ricardo Bemfica Steffen ${ }^{3}$ (1) (https://orcid.org/0000-0003-2736-9329)
}

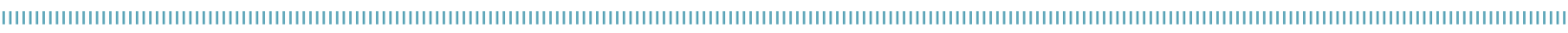

\begin{abstract}
This study aimed to evaluate a strain of Trichogramma pretiosum native to the central region of the state Rio Grande do Sul, Brazil, under different temperatures in laboratory and the parasitism of Helicoverpa zea after releases in corn field. Trichogramma pretiosum females were kept at 18, 25 and $30^{\circ} \mathrm{C}$ and had their parasitism potential evaluated. Nine plots $\left(400 \mathrm{~m}^{2}\right)$ of maize were installed in randomized blocks under the treatments: 1) staggered release of parasitoids in three different occasions, at three-day intervals; 2) a single release of parasitoids; 3) no release of parasitoids. Ears were collected every four days and the number of caterpillars and eggs of H. zea in the maize silk and the number of damaged ears were estimated. Evaluation started after the tassels growth and ended with the drying of the styles-stigmas. To estimate the grain mass and the ear number and mass, two lines in each plot were delimited and reserved at the end of the cultivation cycle. In laboratory, the highest parasitism rate occurred at $25^{\circ} \mathrm{C}(35.54 \%)$ and the lowest longevity at $30^{\circ} \mathrm{C}$ (6.8 days). A total of 1,063 H. zea eggs were collected in the field, $69.52 \%$ were parasitized. The mean parasitism rate was higher in T1 (staggered release, $82.77 \%$ ) than in control (51.87\%), but there was no difference in grain yield. Based on the parasitism capacity of the studied strain, it can be potentially used in programs of biological control of H. zea in corn crops of Rio Grande do Sul.
\end{abstract}

KEYWORDS: Helicoverpa zea; strain; corn; parasitism.

\begin{abstract}
RESUMO: O estudo objetivou avaliar uma linhagem de Trichogramma pretiosum nativa da regiáo Central do Rio Grande do Sul (Brasil) sob diferentes temperaturas em laboratório, e no parasitismo de Helicoverpa zea após liberaçôes em área de milho. Fêmeas de T. pretiosum foram mantidas a 18,25 e $30^{\circ} \mathrm{C}$ e avaliadas quanto ao potencial de parasitismo. No campo, foram instaladas nove parcelas $\left(400 \mathrm{~m}^{2}\right) \mathrm{de}$ milho híbrido em blocos ao acaso, com os seguintes tratamentos: 1) liberaçáo de parasitoides fracionada em três vezes, em intervalos de três dias; 2) liberação em apenas uma ocasião; 3) sem liberação. A cada quatro dias foram coletadas espigas e registrados os danos e o número de lagartas e ovos de $H$. zea dos estilos-estigmas. A avaliação iniciou durante o pendoamento e estendeu-se até a fase de secagem dos estilos-estigma. Duas linhas em cada parcela foram reservadas para avaliação do número e da massa de espigas e grãos. Em laboratório, o maior percentual de parasitismo foi aos $25^{\circ} \mathrm{C}(35,54 \%)$ e a menor longevidade aos $30^{\circ} \mathrm{C}$ ( 6,8 dias $)$. No campo, foram coletados 1.063 ovos de $H$. zea, dos quais $69,52 \%$ estavam parasitados. O percentual médio de parasitismo foi maior com liberação escalonada de T. pretiosum (82,77\%), comparativamente ao controle $(51,87 \%)$, porém, não houve diferença na produção de grãos. Tendo em vista a capacidade de parasitismo da linhagem avaliada, sugere-se que ela possui potencial para ser utilizada em programas de controle biológico da lagarta da espiga no cultivo de milho no Rio Grande do Sul.
\end{abstract}

PALAVRAS-CHAVE: Helicoverpa zea; linhagem; milho; parasitismo.

\footnotetext{
'Secretaria da Agricultura, Pecuária e Desenvolvimento Rural - Departamento de Diagnóstico e Pesquisa Agropecuária - Centro de Pesquisa em Florestas - Santa Maria (RS), Brazil.

${ }^{2}$ Universidade Federal de Santa Maria - Centro de Ciências Rurais - Santa Maria (RS), Brazil.

${ }^{3}$ Bio Tec RS Tecnologia e Consultoria - Santa Maria (RS), Brazil.

*Corresponding author: entomorais@yahoo.com.br

Received on: 10/29/2018. Accepted on: 07/13/2020
} 


\section{INTRODUCTION}

Parasitoids of the genus Trichogramma Westwood (Hymenoptera: Trichogrammatidae) are an important group of natural enemies and comprise the most numerous genus within the Trichogrammatidae family. Trichogramma pretiosum Ryley has a generalist habit, wide geographic distribution, and was recorded in over 240 hosts, being commonly found in lepidopteran eggs (SOUZA et al., 2016; ZUCCHI et al., 2010).

The natural parasitism of Helicoverpa zea (Boddie) eggs (earworm) (Lepidoptera: Noctuidae) by T. pretiosum in corn crops often reaches $50 \%$, but can occasionally reach over $90 \%$ of eggs (SÁ; PARRA, 1994). According to FORESTI et al. (2012), the parasitism rate can be increased with releases of the agent in the field.

The use of commercial strains of T. pretiosum for caterpillar control is a widespread technique among farmers since, compared with chemical insecticides, it is an efficient and low-price method that aims to restrict pesticide use (PARRA, 2010; FIGUEIREDO et al., 2015). However, the lack of information regarding the field release of these strains often results in unsuccessful outcomes and the technique is frequently disbelieved. It is crucial to establish the most appropriate release interval depending on the locality and infestation degree (SÁ; PARRA, 1993).

Although there are evidences of the association between parasitoids and their hosts and the generalist habit of T. pretiosum, the correct use of specific strains is crucial for the success of control programs. Parasitoids have widely variation in their search behavior, host preference, and responses to environmental conditions (HASSAN, 1997) and the correct parasitoid choice improves the chances of success. Several abiotic factors can affect the strain performance and parasitoids of the genus Trichogramma can have their parasitism performance altered at certain thermal limits (PRATISSOLI et al., 2004; BUENO et al., 2010). Variations in microclimate conditions between different regions can also affect the reproductive capacity of different strains (PRATISSOLI et al., 2007).

The state of Rio Grande do Sul (RS) has high thermal amplitude along the corn crop year. The sowing occurs in winter (August) and the second season in summer (January) when temperatures can reach up to $30^{\circ} \mathrm{C}$ (RODRIGUES; SILVA, 2011). Considering that different insect strains can have different reproductive capacity and longevity at different temperatures (PRATISSOLI et al., 2006), the investigation of strains from specific climatic regions can provide crucial information for the augmentative biological control.

This study aims to evaluate the reproductive capacity of a Trichogramma pretiosum strain from the Central region of RS (Brazil) under different temperatures in laboratory conditions. The reproductive capacity was also evaluated during parasitism of Helicoverpa zea after single and staggered releases in experimental corn fields.

\section{MATERIAL AND METHODS}

The T. pretiosum strain was obtained from $H$. zea eggs collected in Santa Maria (RS) in a previous second-season corn crop. All parasitoids were identified at the specific level following the QUERINO; ZUCCHI (2011) methodology. Since all individuals were collected from the same site, they were all considered a single strain. The parasitoids were kept under controlled conditions $\left(25^{\circ} \mathrm{C}\right.$ and $12 \mathrm{~h}$ of light) and multiplied on eggs of the alternative host Anagasta kuehniella (Zeller) (Lepidoptera: Pyralidae) following the methodology proposed by PARRA (1997).

\section{Laboratory}

The bioassays were conducted with $T$. pretiosum females under three different temperatures $\left(18,25\right.$, and $\left.30^{\circ} \mathrm{C}\right)$ and parasitism rates throughout the females' lifetime $\left(25^{\circ} \mathrm{C}\right)$. Twenty $24 \mathrm{~h}$-old females (at each temperature) were isolated in glass test tubes $(0.8 \times 15 \mathrm{~cm})$. Every two days females received one card $\left(1 \mathrm{~cm}^{2}\right)$ with unviable eggs from the alternative host. After the exposure period, the cards were isolated in plastic microtubes and maintained at the respective temperatures. The total number of parasitized eggs and their viability rate, females' longevity, and offspring sex ratio (RS = number of females/number of females + number of males) were estimated for each treatment. The mean values of each variable were analyzed with an ANOVA and results between treatments were compared with a Tukey's test with $5 \%$ significance. The mean number of parasitized eggs per day of life of females at $25^{\circ} \mathrm{C}$ was also compared with a Tukey's test. All analyses were performed in BioEstat 5.0 (AYRES et al., 2007).

\section{Field}

The field work was conducted in the Forestry Research Secretaria da Agricultura, Pecuária e Desenvolvimento Rural, in Santa

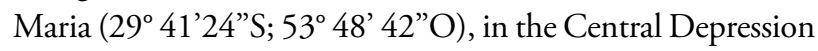
region of RS. On January 22, 2015 the experimental plots (nine $400 \mathrm{~m}^{2}$ areas) were sown with maize from a nontransgenic hybrid cultivar (Fepagro RS 22) using a $0.45 \mathrm{~m}$ distance between lines and $0.66 \mathrm{~m}$ between plants. Plots were separated from each other by at least $20 \mathrm{~m}$ of a same crop. Previous soil analyses were conducted to perform the soil $\mathrm{pH}$ correction and fertilization. Except for the use of Roundup applied prior sowing, planting was carried out without pesticides throughout the entire cycle.

Three treatments were established: 1) Staggered release of parasitoids in three occasions, at three-day intervals; 2) a single release of parasitoids; 3) no release of parasitoids (control). Each treatment was conducted in three plots distributed in random blocks. 
Releases of T1 and T2 were performed at the central point of each plot. Ripe eggs of $A$. kuehniella were glued with Arabic gum on a blue card $\left(10 \mathrm{~cm}^{2}\right)$ fixed on a wooden rod at the center of each plot. The cards were placed in the field on March $24^{\text {th }}, 2015$, after $50 \%$ of the plants had styles-stigmas emission. This procedure was repeated three and six days after the first release in T1. The total number of insects released in each plot of $\mathrm{T} 1$ and $\mathrm{T} 2$ was proportionally equivalent to 200,000 per hectare.

Nearly 65 corn ears were collected every four days. The number of caterpillars and eggs on the styles-stigmas of each corn ear, as well as damaged corn ears, was estimated. The eggs were removed from the styles-stigmas, packed in glass tubes sealed with plastic film, kept in controlled conditions $\left(25^{\circ} \mathrm{C}, 12 \mathrm{~h}\right.$ of light), and monitored daily for the presence of parasitism. The sampling period started immediately after the tassels growth and ended with the complete drying of the styles-stigmas, totalizing 13 sampling occasions.

To estimate the grain mass and the ear number and mass, two lines in each plot were delimited and reserved at the end of the cultivation cycle.

The mean parasitism rate, the mean number of eggs, caterpillars, damaged ears, produced ears, and the mass of ears and grains were compared between treatments with a Kruskal-Wallis test with 5\% significance level. All statistical analyzes were performed in BioEstat 5.0 (AYRES et al., 2007).

\section{RESULTS}

\section{Laboratory}

The mean number of eggs parasitized by females of T. pretiosum kept at $25^{\circ} \mathrm{C}$ was higher than those submitted to temperatures of 18 and $30^{\circ} \mathrm{C}(\mathrm{F}=4.96 ; p<0.05)$. The mean longevity was similar in insects exposed to 18 and $25^{\circ} \mathrm{C}$ and lower in those kept at $30{ }^{\circ} \mathrm{C}(\mathrm{F}=11.34 ; p<0.01)$. The sex ratio and eggs viability were similar in all temperatures (Table 1 ).

The parasitism rate was higher in 3-day-old (23.59 \pm 2.9$)$ and 5-day-old (17.28 \pm 2.35$)$ females kept at $25^{\circ} \mathrm{C}$. Females older than five days had lower parasitism rates $(\mathrm{F}=5.81 ; p<0.05)$.

\section{Field}

A total of 1,063 eggs of H. zea were collected, 739 (69.52\%) were parasitized. The highest number of collected and parasitized eggs was obtained in the first sampling (Fig. 1).

The parasitism rate in $\mathrm{T} 1$ (staggered release) was higher than in T3 (control) $(\mathrm{H}=6.48 ; p=0.039)$ (Table 2).

The mean number of eggs $(\mathrm{H}=5.74 ; p=0.057)$, caterpillars $(\mathrm{H}=1.41 ; p=0.49)$, damaged ears $(\mathrm{H}=0.42 ; p=0.80)$, and ears produced $(\mathrm{H}=4.50 ; p=0.10)$, and the mass of produced ears $(\mathrm{H}=3.59, p=0.30)$ and grains $(\mathrm{H}=0.80 ; p=0.67)$ (Table 2) were similar in all treatments.

\section{DISCUSSION}

The evaluated strain demonstrated low parasitism rates in extreme temperatures. This is a behavior different from what has been recorded for strains from southeast region of Brazil, where the parasitism rate is kept stable in temperatures up to $28{ }^{\circ} \mathrm{C}$ (OLIVEIRA et al., 2017) and $30{ }^{\circ} \mathrm{C}$ (PRATISSOLI et al., 2004). However, the finding corroborates the results of PRATISSOLI et al. (2007) that stated that strains from high-temperatures regions had an altered development after being kept at $20^{\circ} \mathrm{C}$. The authors also found that strains from low-temperature regions had low development rates when subjected to a temperature of $30^{\circ} \mathrm{C}$. Since corn seeding in RS occurs twice a year, in August (low temperatures) and January (high temperatures), comprising a wide temperature range,

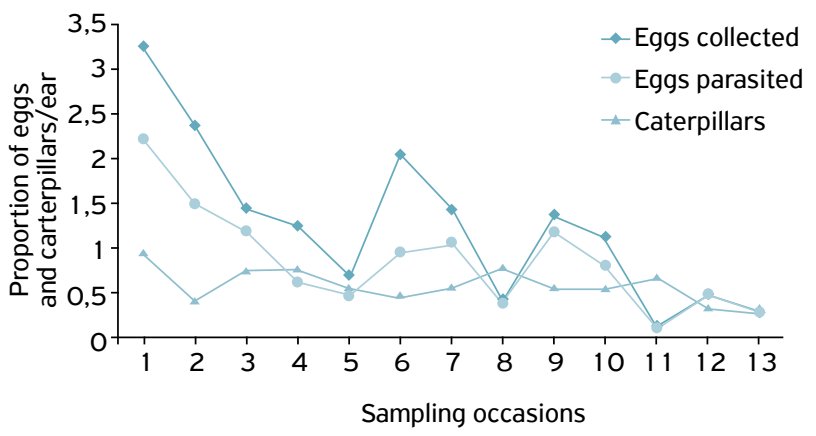

Figure 1. Proportion of eggs of Helicoverpa zea, parasitized eggs, and caterpillars collected per ear in different sampling occasions.

Table 1. Average number ( \pm standard error) of parasitized eggs and females' longevity, percentage of egg viability and offspring sex ratio of Trichogramma pretiosum under different temperatures.

\begin{tabular}{lccccc}
$\begin{array}{l}\text { Temperature } \\
\left({ }^{\circ} \mathrm{C}\right)\end{array}$ & $\begin{array}{c}\text { No of parasitized } \\
\text { eggs }\end{array}$ & $\begin{array}{c}\text { Longevity } \\
\text { (days) }\end{array}$ & $\begin{array}{c}\text { Eggs viability } \\
\text { (\%) }\end{array}$ & \multicolumn{2}{c}{ Sex ratio (\%) } \\
\hline 18 & $35.54 \pm 2.45 \mathrm{~b}^{*}$ & $12.82 \pm 0.72 \mathrm{a}$ & $96.00^{\text {ns }}$ & 53.01 & 47.88 \\
\hline 25 & $50.10 \pm 5.43 \mathrm{a}$ & $12.96 \pm 1.16 \mathrm{a}$ & 97.75 & 46.47 & 53.52 \\
\hline 30 & $32.05 \pm 4.82 \mathrm{~b}$ & $6.8 \pm 0.71 \mathrm{~b}$ & 97.00 & 47.81 & 51.92 \\
\hline
\end{tabular}

*Means followed by different letters in the same column are significantly different between treatments (Tukey's test $p<0.05$ ). ns There wasn't statistical difference between the mean values in the columns without letters. 
Table 2. Mean parasitism rate ( \pm standard error), number of Helicoverpa zea eggs and caterpillars, damaged ears, ears produced, and ears $(\mathrm{g})$ and grains $(\mathrm{g})$ mass in different treatments of experimental corn fields in Santa Maria, RS, Brazil.

\begin{tabular}{lccc} 
& \multicolumn{1}{c}{ T1 $^{*}$} & T2 & T3 \\
Parasitism (\%) & $82.77 \pm 2.46 \mathrm{a}^{* *}$ & $71.71 \pm 6.04 \mathrm{ab}$ & $51.87 \pm 2.22 \mathrm{~b}$ \\
\hline Eggs number & $116.00 \pm 8.97^{\mathrm{ns}}$ & $136.33 \pm 8.82$ & $102.00 \pm 3.00$ \\
\hline Caterpillar number & $50.66 \pm 5.46$ & $55.66 \pm 11.57$ & $58.33 \pm 2.02$ \\
\hline Ear damages number & $26.66 \pm 5.61$ & $30.00 \pm 4.73$ & $31.33 \pm 3.18$ \\
\hline Ears produced number & $50 \pm 6.60$ & $48 \pm 8.19$ & $32.33 \pm 6.53$ \\
\hline Mean ear mass $(\mathrm{g})$ & $101.68 \pm 24.15$ & $96.34 \pm 5.39$ & $94.88 \pm 7.91$ \\
\hline Mean grain mass $(\mathrm{g})$ & $74.73 \pm 17.79$ & $71.20 \pm 3.61$ & $65.83 \pm 10.28$ \\
\hline
\end{tabular}

"T1 = Staggered parasitoid release in three different occasions, in three-day intervals; T2 = a single release of parasitoids; $\mathrm{T} 3=$ No release of parasitoids. "* Means followed by different letters in the same line are significantly different between treatments (Kruskal-Wallis test $p<0.05$ ). ns There wasn't statistical difference between the mean values in the lines without letters.

it is suggested that the studied T. pretiosum strain should be released in months with mild temperatures.

The lower longevity of females at elevated temperatures corroborates the study by PRATISSOLI et al. (2006), in which the mean longevity of T. pretiosum on T. absoluta eggs varied from 1.1 to 11.3 days at temperatures of 30 and $15^{\circ} \mathrm{C}$, respectively. According to the authors, these differences in longevity are related to a physiological response in which the metabolic activity is reduced in low temperatures. The sex ratio was similar in all experimental temperatures, corroborating previous experiments with the same species at temperatures ranging from 18 to $33^{\circ} \mathrm{C}$ (OLIVEIRA et al., 2017).

When monitoring the number of parasitized eggs throughout the females' lifetime, the highest reproductive capacity occurred in the first three days, suggesting that insects released in crops would have to be replaced after this period. This feature was also recorded to five other strains of T. pretiosum kept at $25^{\circ} \mathrm{C}$ which reached over $80 \%$ of parasitism by the fourth day of life (PRATISSOLI et al., 2006).

The highest number of eggs of $H$. zea was collected at the beginning of the sampling period when approximately $50 \%$ of plants had styles-stigmas. In the first two sampling occasions, near $70 \%$ of the collected ears had eggs on them. FORESTI et al. (2013) detected that, when $50 \%$ of the crop had styles-stigmas, only $15 \%$ of those had eggs infestation in the northwest region of RS. Although the infestation rates detected in this study and in the study by FORESTI et al. (2013) were different, there was a similarity related to the gradual reduction in the number of eggs throughout samplings. This corroborates the authors' statement that senescent styles-stigmas become unattractive to $H$. zea oviposition.

Although there were peaks in the eggs rate per ear over the sampling period, the number of caterpillars remained constant. This may be related to the high mortality rates during the first development phase of insects (TOWNSEND et al., 2010). SÁ; PARRA (1993) recorded a predation rate of over $70 \%$ of eggs of $H$. zea in corn crops and predators were mainly comprised by coccinellids, crysopids, and forficulids.
The staggered release of parasitoids provided an increase in the parasitism rate on $H$. zea eggs when compared with control plots. The results showed that, during the first days of females' lifetime, the parasitism efficiency is higher. So, a good strategy would be releasing young and reproductive females in the field in three occasions, at three-day intervals. The two subsequent releases would add parasitoids in the field until those from the first release complete their biological cycle which in mild temperatures is approximately 10 days (PARRA, 1997).

The similar number of $H$. zea eggs between treatments was an expected outcome since the homogeneous oviposition behavior has been already recorded for the species. Studies performed in crops with plants of different varieties, such as landrace, conventional and transgenic hybrids, demonstrated the occurrence of homogeneous oviposition (LUONG et al., 2016; VARGAS et al., 2017).

Although there was a higher parasitism rate in plots with staggered release, there were no differences in the rate of damaged ears between treatments. The expected result of reducing ear damage by adding parasitoids into the crops may not directly occur and depends on several factors such as the density of host eggs in relation to the rate of insects released (PARON et al., 1998). SÁ; PARRA (1993) recorded a $26 \%$ reduction in the damage of $H$. zea after three releases of 100,000 insects per hectare in one experimental area and a $16 \%$ reduction after four releases in other areas. According to the authors, comparative assessments should be conducted in neighboring areas, changing the number of insects and the release time, to complement the number of releases.

The similar ear damage rate between treatments may have impacted the ears and grains mass. In addition, the homogeneous injury caused by fall armyworm, Spodoptera frugiperda (J. E. Smith) (Lepidoptera: Noctuidae), in the experimental plots in the beginning of the vegetative stage may also have compromised the corn production. According to FIGUEIREDO et al. (2006), severe injuries of young plants caused by fall armyworm can result in losses of over $50 \%$ of corn crops. 
The $T$. pretiosum strain from the Central region of RS can be potentially used to control $H$. zea infestations in corn crops due to its high parasitism capacity in field, especially in staggered releases. However, the number of released insects, infestation level monitoring, and the best release period should be better investigated to enable the use of the strain in biological control of corn earworm in crops of south Brazil.

\section{CONCLUSIONS}

The staggered release of T. Pretiosum strain in three occasions, at three-day intervals, increases the parasitism rate on H. zea eggs in corn crops.

The T. pretiosum strain from the central region of the state Rio Grande do Sul has higher reproductive potential at $25^{\circ} \mathrm{C}$.

ACKNOWLEDGEMENTS: The authors are grateful to the Conselho Nacional de Desenvolvimento Científico e Tecnológico for the financial support to second author.

FUNDING: This work did not receive any specific grant from funding agencies in the public, commercial, or not-for-profit sectors. CONFLICTS OF INTEREST: All authors declare that they have no conflict of interest.

ETHICAL APPROVAL: Not applicable.

AVAILABILITY OF DATA AND MATERIAL: All data generated or analyzed during this study are included in this published article.

AUTHORS' CONTRIBUTIONS: Conceptualization: Morais, R.M.; Steffen, G.P.K.; Maldaner, J.; Steffen, R. B. Data curation: Moro, T.S.; Morais, R.M. Formal analysis: Morais, R.M.; Missio, E.; Saldanha, C.W. Writing - review \& editing: Morais, R.M.; Steffen, G.P.K.; Maldaner, J.; Missio, E.; Saldanha, C.W.

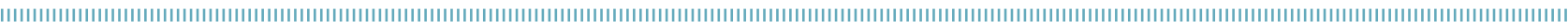
REFERENCES

AYRES, M.; AYRES JUNIOR, M.; AYRES, D.L.; SANTOS, A.A.S. BioEstat 5.0: aplicações estatísticas nas áreas das Ciências Biológicas e Médicas. Belém: Mamirauá/MCT SC, 2007. 364p.

BUENO, R.C.O.F.; BUENO, A.F.; PARRA, J.R.P.; VIEIRA, S.S.; OLIVEIRA, L.J. Biological characteristics and parasitism capacity of Trichogramma pretiosum Riley (Hymenoptera, Trichogrammatidae) on eggs of Spodoptera frugiperda (J. E. Smith) (Lepidoptera, Noctuidae). Revista Brasileira de Entomologia, São Paulo, v.54, n.2, p.322-327, 2010. https://doi.org/10.1590/ S0085-56262010000200016

FIGUEIREDO, M.L.C.; MARTINS-DIAS, A.M.P.; CRUZ, I. Relação entre a lagarta-do-cartucho e seus agentes de controle biológico natural na produção de milho. Pesquisa Agropecuária Brasileira, Brasília, v.41, n.12, p.1693-1698, 2006. https://doi.org/10.1590/ S0 $100-204 \times 2006001200002$

FIGUEIREDO, M.L.C.; CRUZ, I.; SILVA, R.B.; FOSTER, J.E. Biological control with Trichogramma pretiosum increases organic maize productivity by $19.4 \%$. Agronomy for Sustainable Development, Paris, v.35, n.3, p.1175-1 183, 2015. https://doi.org/10.1007/ s13593-015-0312-3

FORESTI, J.; GARCIA, M.S.; BERNARDI, O.; ZART, M.; NUNES, A.M. Biologia, seleção e avaliação de linhagens de Trichogramma spp. para o controle da lagarta-da-espiga em milho semente. EntomoBrasilis, Vassouras, v.5, n.1, p.43-48, 2012. https:// doi.org/10.12741/ebrasilis.v5i1.168
FORESTI, J.; BERNARDI, O.; ZART, M.; GARCIA, M.S.G. Comportamento de oviposição de Helicoverpa zea (Boddie, 1850) (Lepidoptera: Noctuidae) em milho semente e simulação de controle. Revista Brasileira de Milho e Sorgo, Sete Lagoas, v.12, n. 1, p.78-84, 2013. https://doi.org/10.18512/1980-6477/rbms.v12n1 p78-84

HASSAN, S.A. Seleção de espécies de Trichogramma para uso em programas de controle biológico. In: PARRA, J.R.P.; ZUCCHI, R.A. Trichogramma e o controle biológico aplicado. Piracicaba: FEALQ, 1997. 324p.

LUONG, T.T.A.; DOWNES, S.J.; CRIBB, B.; PERKINS, L.E.; ZALUCKI, M.P. Oviposition site selection and survival of susceptible and resistant larvae of Helicoverpa armigera (Lepidoptera: Noctuidae) on Bt and non-Bt cotton. Bulletin of Entomological Research, Brisbane, v. 106, n.6, p.710717, 2016. https://doi.org/10.1017/S0007485316000328

OLIVEIRA, C.M.; OLIVEIRA, J.V.; BARBOSA D.R.S.; BREDA, M.O.; FRANÇA, S. M.; DUARTE, B.L.R. Biological parameters and thermal requirements of Trichogramma pretiosum for the management of the tomato fruit borer (Lepidoptera: Crambidae) in tomatoes. Crop Protection, Lincoln, v.99, p.39-44, 2017. https://doi. org/10.1016/j.cropro.2017.04.005

PARON, M.J.F.O.; CIOCIOLA, A.I.; CRUZ, I. Resposta de Trichogramma atopovirilia Oatman \& Platner (Hymenoptera: Trichogrammatidae) a diferentes densidades de ovos do hospedeiro natural, Helicoverpa zea (Boddie) (Lepidoptera: Noctuidae). Anais da Sociedade Entomológica do Brasil, Londrina, v.27, n.3, p.427-433, 1998. https://doi.org/10.1590/S0301-80591998000300011 
PARRA, J.R.P. Técnicas de criação de Anagasta kuehniella, hospedeiro alternativo para a produção de Trichogramma. In: PARRA, J.R.P.; ZUCCHI, R.A. (eds). Trichogramma e o controle biológico aplicado. Piracicaba: FEALQ, 1997. 324p.

PARRA, J.R.P. Egg parasitoids commercialization in the New World. In: CONSOLI, F.L.; PARRA, J.R.P.; ZUCCHI, R.A. (eds). Egg Parasitoids in Agroecosystems with Emphasis on Trichogramma. Dordrecht: Springer, 2010. chap.14, p.373-388. https:// doi.org/10.1007/978-1-4020-9110-0_14

PRATISSOLI, D.; ZANUNCIO, J.; VIANNA, U.R.; ANDRADE, J.S.; GUIMARÃES, E.M.; ESPINDULA, M.C. Fertility life table of Trichogramma pretiosum and Trichogramma acacioi on eggs of Anagasta kuehniella at different temperatures. Pesquisa Agropecuária Brasileira, Brasília, v.39, n.2, p. 193-196, 2004. https://doi.org/10.1590/SO100-204X2004000200014

PRATISSOLI, D.; THULER, R.T.; SILVA, A.F.; DALVI, L.P.; TAMANHONI, T. Características biológicas de linhagens de Trichogramma pretiosum, criadas em ovos de Tuta absoluta, em diferentes temperaturas. Científica, Jaboticabal, v.34, n.2, p.210-216, 2006. Available from: http://cientifica. org.br/index.php/cientifica/article/view/120. Access on: 30 Aug. 2018.

PRATISSOLI, D.; POLANCZYK, R.A.; ANDRADE, G.S.; HOLTZ, A.M.; SILVA, A.F.; PASTORI, P.L. Tabela de vida de fertilidade de cinco linhagens de Trichogramma pretiosum Riley (Hym.: Trichogrammatidae) criadas em ovos de Tuta absoluta (Merick) (Lep.: Gelechiidae), sob temperaturas constantes e alternadas. Ciência Rural, Santa Maria, v.37, n.3, p.618-622, 2007. https:// doi.org/10.1590/SO103-84782007000300003

QUERINO, R.B.; ZUCCHI, R.A. Guia de identificação de Trichogramma para o Brasil. Brasília: Embrapa, 2011 . 103p.
RODRIGUES, L.R.; SILVA, P.R.F. Indicações técnicas para o cultivo de milho e de sorgo no Rio Grande do Sul: Safras 201 1/2012 e 2012/2013. Porto Alegre: Fepagro, 2011.140 p. Available from: http://www. fepagro.rs.gov.br/upload/20120727094341 indicacoes_tecnicas_ milho_e_sorgo_2011.pdf. Access on: 3 Sep. 2018.

SÁ, L.A.N.; PARRA, J.R.P. Efeito do número e intervalo entre liberações de Trichogramma pretiosum Riley no parasitismo e controle de Helicoverpa zea (Boddie) em milho. Scientia Agricola, Piracicaba, v.50, n.3, p.355-359, 1993. https://doi.org/10.1590/ S0103-90161993000300006

SÁ, L.A.N.; PARRA, J.R.P. Natural parasitism of Spodoptera frugiperda and Helicoverpa zea (Lepidoptera: Noctuidae) eggs in corn by Trichogramma pretiosum (Hymenoptera: Trichogrammatidae) in Brazil. Florida Entomologist, Gainesville, v.77, n. 1, p.185-188, 1994. https://doi.org/10.2307/3495886

SOUZA, A.R.; GIUSTOLIN, T.A.; QUERINO, R.B.; ALVARENGA, C.D. Natural parasitism of lepidopteran eggs by Trichogramma species (Hymenoptera: Trichogrammatidae) in agricultural crops in Minas Gerais, Brazil. Florida Entomologist, Gainesville, v.99, n.2, p.221-225, 2016. https://doi.org/10.1653/024.099.0210

TOWNSEND, C.R.; BEGON, M.; HARPER, J.L. (ed.). Fundamentos em Ecologia. Porto Alegre: Artmed, 2010. 576p.

VARGAS, C.C.; MORAIS, R.M.; REDAELLI, L.R. Infestação de milho crioulo, convencional e transgênico pela lagarta-do-cartucho e pela lagarta-da-espiga e parasitismo de ovos. Revista Brasileira de Milho e Sorgo, Sete Lagoas, v.16, n.3, p.351-360, 2017. https://doi.org/10.18512/1980-6477/rbms.v16n3p351-360

ZUCCHI, R.A.; QUERINO, R.B.; MONTEIRO, R.C. Diversity and hosts of Trichogramma in the New World, with emphasis in South America. In: CONSOLI, F.L.; PARRA, J.R.P.; ZUCCHI, R.A. (eds). Egg Parasitoids in Agroecosystems with Emphasis on Trichogramma. Dordrecht: Springer, 2010. chap.8, p.219-236. https://doi. org/10.1007/978-1-4020-9110-0_8 